\title{
Can We Grow Valves Inside the Heart? Perspective on Material- based In Situ Heart Valve Tissue Engineering
}

\author{
Carlijn V. C. Bouten ${ }^{1,2 *}$, Anthal I. P. M. Smits ${ }^{1,2}$ and Frank P. T. Baaijens ${ }^{1,2}$ \\ ${ }^{1}$ Soft Tissue Engineering and Mechanobiology, Department of Biomedical Engineering, Eindhoven University of Technology, \\ Eindhoven, Netherlands, ${ }^{2}$ Institute for Complex Molecular Systems (ICMS), Eindhoven University of Technology, Eindhoven, \\ Netherlands
}

\section{OPEN ACCESS}

Edited by:

Joshua D. Hutcheson,

Florida International University,

United States

Reviewed by:

Sergio Bertazzo,

University College London,

United Kingdom

Katherine Yutzey,

Cincinnati Children's Hospital Medical

Center, United States

*Correspondence:

Carlijn V. C. Bouten

c.v.c.bouten@tue.nl

Specialty section:

This article was submitted to

Atherosclerosis and

Vascular Medicine,

a section of the journal

Frontiers in Cardiovascular Medicine

Received: 31 January 2018 Accepted: 09 May 2018

Published: 29 May 2018

Citation:

Bouten CVC, Smits AIPM and

Baaijens FPT

(2018) Can We Grow Valves Inside

the Heart? Perspective on

Material-based In Situ Heart Valve

Tissue Engineering.

Front. Cardiovasc. Med. 5:54.

doi: 10.3389/fcvm.2018.00054
In situ heart valve tissue engineering using cell-free synthetic, biodegradable scaffolds is under development as a clinically attractive approach to create living valves right inside the heart of a patient. In this approach, a valve-shaped porous scaffold "implant" is rapidly populated by endogenous cells that initiate neo-tissue formation in pace with scaffold degradation. While this may constitute a cost-effective procedure, compatible with regulatory and clinical standards worldwide, the new technology heavily relies on the development of advanced biomaterials, the processing thereof into (minimally invasive deliverable) scaffolds, and the interaction of such materials with endogenous cells and neo-tissue under hemodynamic conditions. Despite the first positive preclinical results and the initiation of a small-scale clinical trial by commercial parties, in situ tissue formation is not well understood. In addition, it remains to be determined whether the resulting neo-tissue can grow with the body and preserves functional homeostasis throughout life. More important yet, it is still unknown if and how in situ tissue formation can be controlled under conditions of genetic or acquired disease. Here, we discuss the recent advances of material-based in situ heart valve tissue engineering and highlight the most critical issues that remain before clinical application can be expected. We argue that a combination of basic science - unveiling the mechanisms of the human body to respond to the implanted biomaterial under (patho)physiological conditions - and technological advancements - relating to the development of next generation materials and the prediction of in situ tissue growth and adaptation - is essential to take the next step towards a realistic and rewarding translation of in situ heart valve tissue engineering.

Keywords: endogenous regeneration, biomaterials, host response, tissue remodeling, clinical translation

\section{INTRODUCTION}

Since the introduction of the first artificial aortic heart valve by Hufnagel et al. more than six decades ago (1), heart valve prosthesis design has seen revolutionary changes in the endeavor to reduce prosthesis-related complications and to treat diverse patient groups. These include the development of bio-prostheses consisting of preserved human or animal tissue $(2,3)$ and the recent introduction of valve designs for transcatheter valve replacement (4). A true paradigm change, however, has been the construction of living valves through the process of tissue engineering. Conventional tissue engineering, 
also named in vitro tissue engineering, is defined as the culture of cells - preferably from an autologous source - in combination with a degradable scaffold, to create a living implant or a living tissue mimic outside the human body (5). Living heart valve prostheses offer the potential to grow and adapt to changes in physiological demand and, as such, can last a lifetime. This was conceived as the holy grail for pediatric patients and the increasing number of patients with "grown up congenital heart disease" (GUCH), who will need one or more heart valve replacements later in life (6). Despite encouraging exemplary results $(7,8)$ and numerous modifications to the procedure (9-12), however, clinical translation has proven difficult. This is primarily caused by suboptimal long term in vivo results due to cell traction, consequent valve leaflet retraction, and unforeseen host responses to the constructs after implantation (13-16). In addition, clinical translation is hindered by the logistic and regulatory complexity of the procedures, very limited shelf life, and costly cell and tissue culture in specialized laboratories, restricting the therapy to developed Western countries (17). These drawbacks have led clinicians and scientists to wonder if heart valve tissue engineering (HVTE) will ever make a difference in heart valve replacement therapy (18).

\section{In Situ Heart Valve Tissue Engineering}

Inspired by the in vivo host response of living tissue engineered valves, and to resolve the issue of cell traction-induced leaflet retraction, the concept of in situ HVTE using acelluar starter matrices is explored by different groups (See Table 1). For instance, de-cellularized in vitro

TABLE 1 | Selection of (pre)clinical studies on in situ tissue engineered heart valves.

\begin{tabular}{|c|c|c|c|}
\hline Material type & Model & Main findings/status & Refs. \\
\hline \multicolumn{4}{|l|}{ Decellularized allografts } \\
\hline Decell. allografts & $\begin{array}{l}\text { PV and AV replacements in ovine } \\
\text { and porcine models }\end{array}$ & $\begin{array}{l}\text { Less calcification and improved durability compared to cryopreserved } \\
\text { valves. Adequate nctionality demonstrated in juvenile, growing sheep, as } \\
\text { well as elderly sheep. Cellularization typically persistent but partial. }\end{array}$ & $(19-25)$ \\
\hline Decell. allografts & $\begin{array}{l}\text { PV replacement in children and } \\
\text { young adults }\end{array}$ & $\begin{array}{l}\text { Improved freedom from reoperations. Partial cellularization of the leaflet. } \\
\text { No systemic immune response. }\end{array}$ & $(26-28)$ \\
\hline $\begin{array}{l}\text { Decell. allografts + collagen } \\
\text { conditioning treatment }\end{array}$ & $\begin{array}{l}\text { PV replacement in baboons and } \\
\text { growing lambs }\end{array}$ & $\begin{array}{l}\text { Decreased antigenicity and improved somatic growth potential by } \\
\text { collagen conditioning treatment. }\end{array}$ & $(29,30)$ \\
\hline \multicolumn{4}{|l|}{ Decellularized xenografts } \\
\hline Decell. xenografts (porcine) & $\begin{array}{l}\text { PV replacement in adults and } \\
\text { children }\end{array}$ & $\begin{array}{l}\text { Mixed clinical results. Recellularization potential and immunological } \\
\text { compatibility seems strongly dependent on decellularization and } \\
\text { cryopreservation methods. }\end{array}$ & $(31-34)$ \\
\hline $\begin{array}{l}\text { Decell. xenografts + various } \\
\text { functionalizations }\end{array}$ & $\begin{array}{l}\text { PV replacement in ovine and canine } \\
\text { models }\end{array}$ & $\begin{array}{l}\text { Various functionalization treatments to improve in situ recellularization, } \\
\text { including CD133ab, HEP/HGF, G-CSF. }\end{array}$ & $(35-37)$ \\
\hline Decell. xenografts + PHB coatings & PV and AV replacements in sheep & $\begin{array}{l}\text { Hybrid polymer-coated decellularized xenografts to improve mechanical } \\
\text { and structural properties. }\end{array}$ & $(38,39)$ \\
\hline \multicolumn{4}{|l|}{ Decellularized ECM } \\
\hline Decell. SIS (CorMatrix) & $\begin{array}{l}\text { Various valve replacements (PV, AV, } \\
\mathrm{MV} \text { ) in children and adults }\end{array}$ & $\begin{array}{l}\text { Mixed immunological response of remodeling and inflammation. Reports } \\
\text { of severe insufficiency and degeneration. Consistent reporting of no } \\
\text { remodeling into the typical 3-layered valve structure. }\end{array}$ & $(40-42)$ \\
\hline Decell. SIS (CorMatrix) & TV replacement in pig & $\begin{array}{l}\text { In situ cellularization and remodeling reported, with potential for growth. } \\
\text { Severe paravalvular regurgitation. }\end{array}$ & $(43,44)$ \\
\hline \multicolumn{4}{|c|}{ Decellularized de novo tissue-engineered heart valves } \\
\hline Decell. homologous TEHVs & $\begin{array}{l}\text { Minimally-invasively implanted PV in } \\
\text { sheep and non-human primates }\end{array}$ & $\begin{array}{l}\text { Decellularized TEHV technology compatible with minimally-invasive valve } \\
\text { delivery. Extensive in situ cellularization of leaflets and tissue remodeling, } \\
\text { including elastogenesis. Leaflet retraction and regurgitation at }>8 \text { weeks } \\
\text { follow-up. }\end{array}$ & $(45-47)$ \\
\hline Decell. tubular TEHVs & $\begin{array}{l}\text { Implantation as AV in sheep and PV } \\
\text { in growing lambs }\end{array}$ & $\begin{array}{l}\text { Extensive cellularization of leaflets and tissue remodeling, including } \\
\text { elastogenesis. Sustained functionality for } 6 \text {-months as AV. Progressive } \\
\text { regurgitation of PVs in growing lambs. }\end{array}$ & $(48,49)$ \\
\hline \multicolumn{4}{|l|}{ Resorbable synthetic valves } \\
\hline $\begin{array}{l}\text { PGA/P4HB, on-the-fly preseeded } \\
\text { with BMCs }\end{array}$ & $\begin{array}{l}\text { Transapically delivered } \mathrm{AV} \text { in sheep } \\
\text { and } \mathrm{PV} \text { in non-human primates }\end{array}$ & $\begin{array}{l}\text { Feasiblity of technology demonstrated with acute valve functionality. } \\
\text { Rapid polymer resorption }\end{array}$ & $(50,51)$ \\
\hline $\mathrm{P} 4 \mathrm{HB} /$ gelatin hybrid & Transapically delivered PV in sheep & Feasiblity of technology demonstrated with acute valve functionality. & $(52)$ \\
\hline $\begin{array}{l}\text { Slow-degrading supramolecular } \\
\text { elastomers }\end{array}$ & $\mathrm{PV}$ and $\mathrm{AV}$ replacements in sheep & $\begin{array}{l}\text { Sustained 1-year functionality with extensive in situ cellularization and } \\
\text { tissue formation. Proof-of-concept for in situ TEHV using resorbable } \\
\text { synthetic valves. Compatible with minimally-invasive delivery in PV and AV } \\
\text { positions. }\end{array}$ & $(53-55)$ \\
\hline $\begin{array}{l}\text { Slow-degrading supramolecular } \\
\text { elastomers }\end{array}$ & $\begin{array}{l}\text { PV replacements in pediatric } \\
\text { patients }\end{array}$ & $\begin{array}{l}\text { First ongoing clinical trials using resorbable synthetic valves (Xeltis XPlore-I } \\
\text { and XPlore-II, NCT numbers: NCT02700100, NCT03022708). }\end{array}$ & - \\
\hline
\end{tabular}

AV, aortic valve; BMCs, bone marrow-derived cells.; G-CSF, granuloctye colony stimulating factor; HEP, heparin; HGF, hepatocyte growth factor; MV, mitral valve; P4HB, poly-4-hydroxybutyrate; PGA, polyglycolic acid; PHB, polyhydroxybutyrate; PV, pulmonary valve; SIS, small intestine submucosa; TEHV, tissue-engineered heart valve; TV, tricuspid valve. 
engineered heart valves have been developed $(56,57)$. This approach aims at the creation of a living valve at the site of implantation using a cell-free, yet in vitro cultured, extracellular matrix that recruits endogenous cells after implantation. In contrast to de-cellularized xenografts and homografts $(19,27,28,58)$ de novo engineered matrix valves do not depend on the availability of a donor valve or tissue. These de novo engineered matrices show rapid repopulation with host cells required for growth and remodeling, both in sheep and nonhuman primates $(45,46,48,49)$. As such, the outlooks for clinical application are promising, but creation of these valves is still laborious and costly.

In recent years the use of biodegradable synthetic starter matrices has emerged as an alternative technology to grow living valves inside the heart (59). This technology offers readily available valvular grafts at substantially reduced costs. Porous synthetic polymer scaffolds are attractive candidates for the procedure as they can be rationally designed to accommodate cell recruitment and orchestrate tissue formation, while maintaining valve functionality. The technology is compatible with current regulatory frameworks for medical devices and artificial heart valves and exquisitely suited for both surgical and transcatheter valve delivery. We have investigated in situ HVTE using a slow-degrading electrospun bis-urea-modified polycarbonate elastomeric graft (55). When implanted as a surgical pulmonary valve replacement in sheep, valves maintained hemodynamic performance over a 12-month follow-up period as endogenous cells that produced a native-like, layered extracellular matrix slowly replaced the graft (Figure 1B). Transapically delivered pulmonary valves in Nitinol stents showed similar native-like matrix formation and good hemodynamic performance over a 6-month follow-up period.

Although this concept is widely explored for in situ engineered vascular grafts, leading to exciting preclinical and clinical trials (e.g., reviewed by 60 and 61), this was the first long-term pre-clinical proof of concept that in situ formation of living valvular tissue is possible without the use of any donor tissue or even in vitro cell and tissue culture. In parallel to - and independent of - this scientific proof of concept ongoing commercial developments of biodegradable polymer pulmonary valves have recently led to a small-scale clinical trial in pediatric patients (Xplore-I and Xplore-II trials) as well as the preclinical exploration of transcatheter aortic heart valves (62).

Despite these developments, complete understanding of neotissue formation is missing. In addition, growth of in situ engineered heart valves has not been demonstrated yet. Next to ongoing longterm in vivo investigation of the technology, a number of scientific and technological challenges must be addressed before in situ HVTE can be translated into a routine clinical practice. Below, we highlight the most critical issues.

\section{OUTSTANDING CHALLENGES}

\section{Understanding Materials-Driven Regeneration}

Regenerative medicine in general - and in situ tissue engineering in particular - builds on the intrinsic self-healing and regenerative capacity of the human body. Hence, for in situ HVTE to be successful and safe, our understanding of the intelligent and diverse ways of human tissue adaptation and regeneration in response to a non-living degrading biomaterial under hemodynamic conditions is critical. Since this knowledge is virtually missing, the prime challenge is to develop a mechanistic understanding of materialsdriven valve regeneration and unveil the potential and limitations of in situ HVTE under various (patho)physiological circumstances.

The core concept of in situ HVTE is that a degradable synthetic heart valve scaffold transforms into viable tissue with growth potential via an inflammatory response to the scaffold (Figure 1A). While little experimental data regarding the fundamental inflammatory and regenerative processes underlying in situ HVTE is available, mechanistic data from developmental biology and other in situ TE applications may give us more insight into these processes, as reviewed in more detail elsewhere (63). Specifically, studies employing resorbable vascular grafts have demonstrated that the host response to such an implanted grafts in the bloodstream is a cascade of events, initiated by the acute inflammatory response (64).

Upon implantation, the scaffold is first and foremost colonized by immune cells from the bloodstream (e.g., granulocytes, monocytes), followed by recruitment of progenitor cells, macrophages, lymphocytes, and tissue forming cells from blood and adjacent tissue, which are attracted by inflammatory cytokines and chemokines expressed by the immune cells. Next, the scaffold is degraded by foreign body giant cells while endogenous extracellular matrix is produced. Studies on highly regenerative species, such as axolotls, zebrafish and African spiny mice have demonstrated that macrophages are critical for regeneration (65-67). Similarly Hibino et al. demonstrated that systemic macrophage depletion led to a complete abrogation of regeneration of in situ TE vascular grafts in mice (68).

By coordinating the initial infiltration and differentiation of innate immune cells into the scaffold, the inflammatory response can potentially be harnessed to avoid chronic inflammation and tissue fibrosis (69). While the role of macrophage polarization in heart valve regeneration remains to be elucidated, it has been postulated that the differentiation of monocytes towards a regenerative macrophage (M2) phenotype should be enhanced early in the process to create the prerequisite initial conditions for stable tissue formation $(70,71)$. Additionally, recent data on the biomaterial-driven regeneration of skeletal muscle revealed an essential role for $\mathrm{T}$ helper 2 cells in the macrophage-driven regeneration (72). Following these initial processes, graft endothelialization and functional matrix organization (i.e., anisotropy, layered-ness) must be achieved, while preventing adverse effects like neo-intima hyperplasia, valvular fibrosis and calcification. The exact origin of the colonizing mature tissue cells remains speculative. With respect to endothelialization, studies in rodents have suggested transanastomotic ingrowth as the primary source of endothelial cells (73). However, the relevance of this suggestion for the human scenario has been contested, and recently transmural capillary ingrowth has been indicated as the primary route of endothelialization (74).

Our own preclinical results have indeed verified the above processes when using macro-porous, degradable electrospun scaffolds. Upon implantation the scaffolds were immediately colonized by immune 
A. Synthetic heart valve

Inflammation Neotissue formation Remodeling Homeostasis
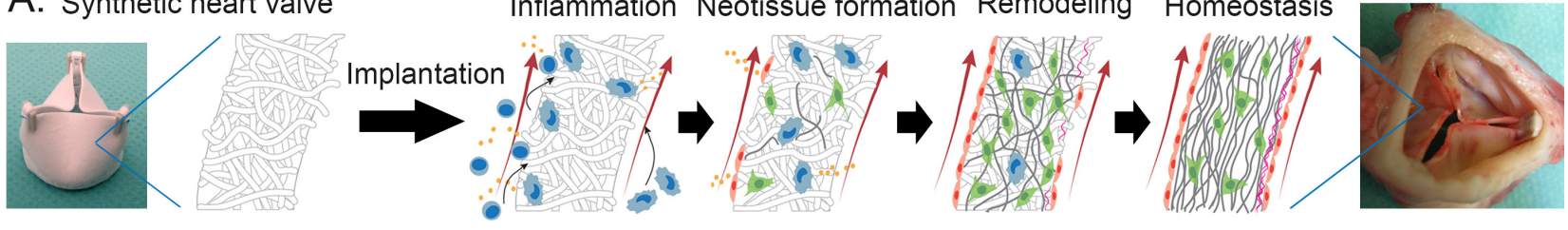

B.
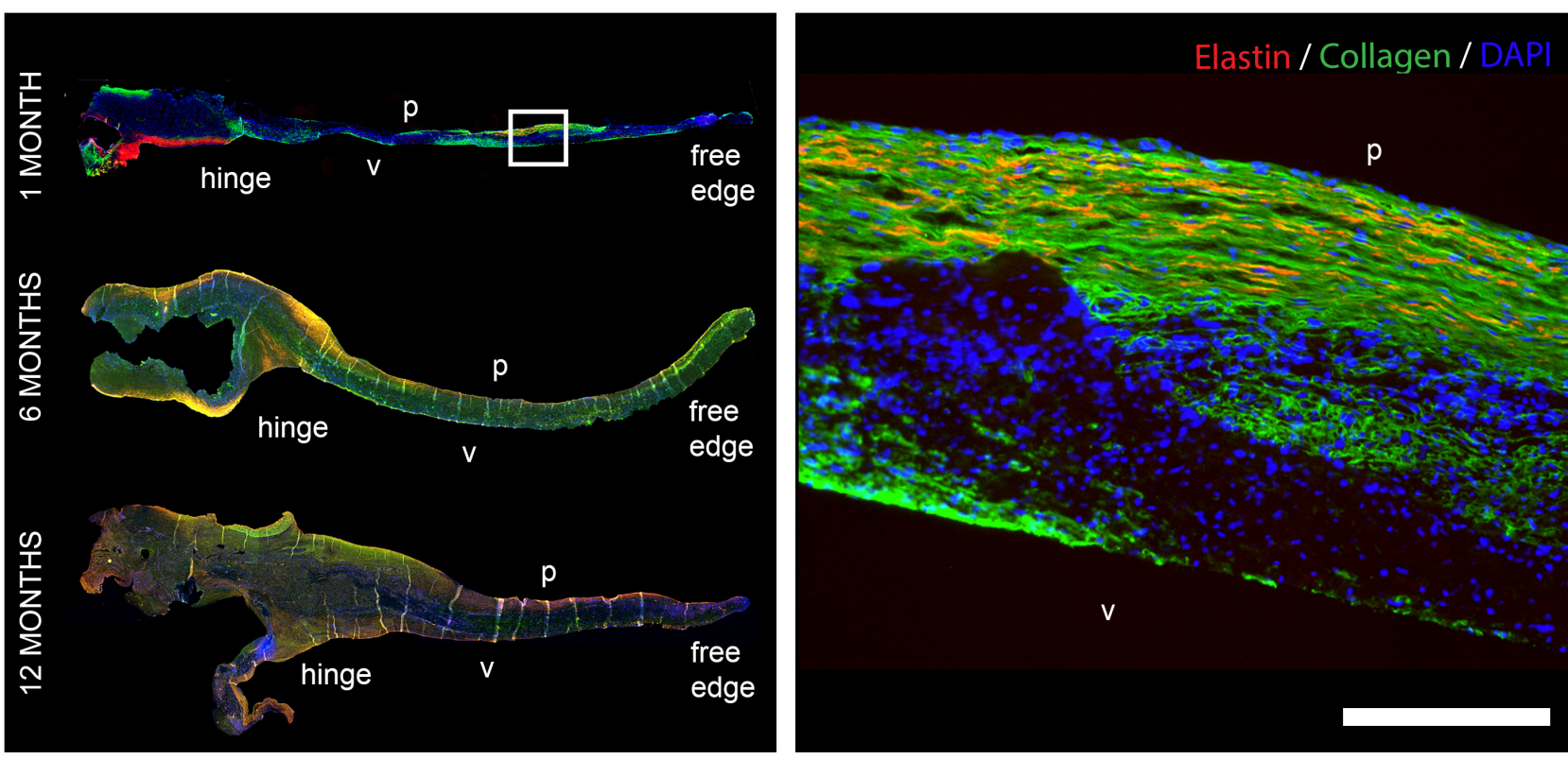

C.
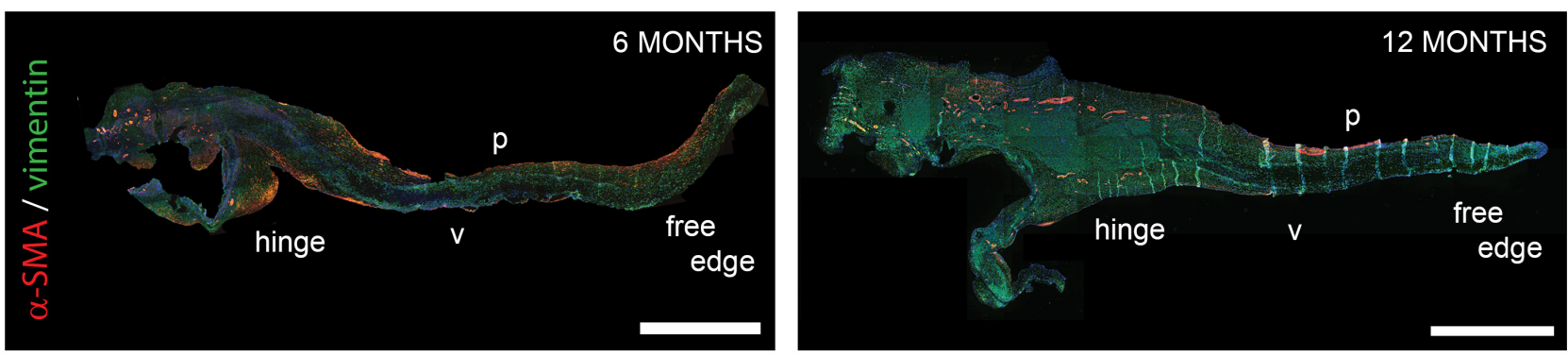

FIGURE 1 | (A) Schematic representation of the hypothesized sequence of events, transforming an acellular synthetic valvular scaffold into an autologous, living heart valve in situ. After implantation, the implantation of the foreign material triggers an inflammatory response, which subsequently induces the formation of new tissue, while the initial synthetic scaffold is being degraded. Ideally, the newly formed tissue is remodeled to attain the well-organized native-like three-layered structure of the valve, with the goal of achieving tissue homeostasis. B. Neo-matrix formation in the leaflet of an in situ engineered heart valve, 1 month, 6 months and 12 months post implantation, grown from a slow degrading electrospun elastomeric (bis-urea-modified polycarbonate) scaffold in the pulmonary position in sheep. A layered structure containing cells (DAPI, blue), and collagen (green) co-localized with elastin (red) can be observed in the longitudinal sections. C.

Cellularization of in situ engineered valves with predominantly vimentin (green) expressing mesenchymal cells and decreasing presence of $\alpha$-smooth muscle actin (red) expressing active myofibroblast-like cells from 6 to 12 months after implantation. p: pulmonary side; v: ventricular side of the leaflet. Scale bars represent 200 $\mu \mathrm{m}$ (B) and $1 \mathrm{~mm}$ (C). Subfigures A and C are adapted and reprinted from (55) with permission from Elsevier. Subfigure B is courtesy of Sylvia Dekker, Eindhoven University of Technology.

cells from the bloodstream, followed by recruitment of macrophages and tissue forming myofibroblast-like $\alpha-\mathrm{SMA}^{+}$and fibroblast-like vimentin $^{+}$cells from blood and adjacent tissue (valvular root) to eventually achieve a stable, quiescent $\alpha-\mathrm{SMA}^{-} /$vimentin ${ }^{+}$valvular interstitial-like cell phenotype (Figure 1C). In addition, a layered ECM was developed, with mature collagen and elastin fibers, covered by a confluent endothelium weeks to months after implantation (21, 75). It remains to be elucidated if in situ tissue development will be 
similar under more demanding conditions, such as in case of aortic valve replacement.

Systematic analysis of immune cell recruitment and polarization in preclinical studies, relevant for profound mechanistic understanding, requires the development of species-specific markers (76). More importantly, innate and adaptive immune responses may differ among species (77-79), strongly reducing the impact and translation of preclinical observations for human insights. For translational purposes it should furthermore be noted that the inflammatory host response and subsequent matrix formation is different in young versus old patients (80, 81 ), and can be affected by common comorbidities, like diabetes or kidney disease, common in older patients requiring heart valve replacements (82-85). Finally, it is far from clear if and how in situ tissue regeneration can be controlled under conditions of genetic or acquired disease.

In order to deal with the above-mentioned inter-species and inter-patient variability in the processes of material-driven inflammation and regeneration, the development of dedicated models is paramount. In vitro engineered laboratory models, based on human cells (either healthy or diseased) can be exploited to gain an initial understanding of tissue integration and remodeling in response to scaffolds (e.g., reviewed by 86 and 87). Dynamic in vitro co-culture platforms are eminently suitable to screen the interactions between human (circulatory) immune cells and valvular scaffolds under physiologically relevant hemodynamic stimuli, such as shear stress (88-90) and cyclic strains $(91,92)$. By using primary patient-derived cells, the influence of patient-specific characteristics on the cellscaffold interactions can be assessed (e.g., 93, 94) Accordingly, preclinical animal models are increasingly being tailored to match specific clinical scenarios, for example by considering age (35), induced pathologies (38), or by using humanized animal models (95) or genetically modified animal models e.g., via CRISPR technologies $(96,97)$. All in all, the development of such refined, more personalized in vitro and in vivo models enables the fundamental unraveling of materials-driven regeneration for a wide range of patient populations.

\section{Biomaterial Development and Rational Scaffold Design}

Although the use of synthetic degradable materials as valve replacement is attractive from a clinical perspective, the success of this approach fully depends on the generation of sophisticated biomaterials and the processing thereof into valvular scaffolds. For secured valve functionality, these scaffolds should: (i) take over valve functionality immediately upon implantation, thus providing structural and mechanical support; (ii) fully interact and integrate with their biological environment, instructing and guiding neo-tissue formation by providing a microenvironment with the necessary biochemical and biophysical cues for cells to home, stabilize, synthesize, and organize their own load-bearing extracellular matrix. (iii) maintain tissue functionality at all times, thus degrading in pace with neo-tissue formation and permitting matrix homeostasis and remodeling to evolving functional demands; and (iv) result in completely endogenous and well- structured, layered and endothelialized valves that can adapt to somatic growth.

These demands are relevant across lengths scales. For instance, valve functionality (opening and closing, load-bearing properties) is determined by macroscopic mm-cm scale properties of the valvular scaffold, such as valve geometry, while cell behavior is mainly dependent on microscale properties, like porosity or chemical composition of the scaffold. Degradation profiles, on the other hand, will affect both microscopic and macroscopic properties.

Nowadays, many biomaterials and scaffolds are designed to induce tissue formation or even regeneration through direct interactions with proteins and cells via e.g., chemical function and binding affinity, but also via biophysical properties, like stiffness and nano-, micro- and mesoscale topologies (98-100). Revolutionary improvements in materials science, especially in the area of supramolecular polymers $(101,102)$ have recently resulted in the development of a new class of biomaterials that can be rendered bioactive and bioresponsive via the appending of functional moieties and tuned with respect to mechanical properties and degradation rate/mechanisms through simple "mix-and-match" assembly. These dynamic materials can interact with the biological system in an almost natural way; instructing and responding to cells and offering full control over the cellular environment. At the same time, they can be used to restore large defects, while providing temporary mechanical and structural support. Recent results with SDF-1a functionalized scaffolds, for instance, demonstrate the potential of these materials in the cardiovascular system (103).

A main challenge is to develop instructive materials that are capable of harnessing the inevitable host response, for instance by selective recruitment of immune cells or by skewing macrophage polarization. Previous studies indicate that macrophage polarization in cell-free scaffolds can be achieved via the release of specific cytokines and trophic factors (MCP-1, SDF1a, bFGF; 64, 68, 104). More recent findings, however, demonstrate that the biophysical microevironment (strain, shear stress, anisotropy) experienced by infiltrating monocytes suffices to modulate macrophage polarization $(44,51,105)$. As this would prevent the use of bioactive moieties, the processing of materials into scaffolds with the right initial microstructure might suffice to control the delicate balance between fibrotic and regenerative tissue formation.

Valvular scaffolds have been processed from a wide range of synthetic biomaterials $(106,107)$ using processing methods like electrospinning $(108,109), 3 \mathrm{D}$ printing $(110)$, direct write melt electrospinning (111), jet spinning (52), and double component electrodeposition (112) to control valve macro and microstructure. The outcomes of these studies suggest that controlling leaflet shape and thickness, as well as pore size (for rapid cell repopulation, 113) are among the most critical parameters for ultimate valve function and regeneration.

Still, scaffold development for in situ HVTE would benefit greatly from systematic studies on the effects of individual and combined micro and microscale properties on valve function and regeneration. These should include currently unexplored properties like blood-scaffold interactions under anticoagulation therapy (114) and antimicrobial properties (115). The systematic 
studies may take advantage from the above-mentioned in vitro models for screening candidate materials and even move towards the development of personalized scaffolds. Given the myriad of possible combinations, however, high-throughput analysis techniques combined with data mining may be a faster option $(116,117)$.

\section{Predicting Tissue Development and Growth}

Computational modeling can also accelerate scaffold design across length scales. A significant example is the development of a predictive computational model to generate new testable hypotheses for scaffold properties that favor tissue engineered neovessel formation and function (118). For HVTE such models are scarce but indispensible. Initially, computational analysis focused at the biomechanics of heart valves and was directed at understanding the stress and strain distribution in the valve leaflets and valve root in relation to the geometry and mechanical properties of the tissues (e.g., reviewed in 119, 120). In particular, the impact of the collagen fiber architecture on the deformation patterns was investigated $(121,122)$. To this end, constitutive models with increasing complexity where developed to capture the microstructure of the valve. Upon the development of dedicated fluid-structure interaction algorithms, these models could also be used to investigate the impact of the microstructure on the opening and closing behavior of the valve leaflets (123). It was found that collagen fiber architecture not only significantly impact tissue stresses and strains during diastole, their predominant circumferential orientation also has a large effect on valve opening during systole and contribute to the stability of valve motion (124). These observations are likely relevant for valvular scaffolds as well and can be translated into "scaffold leaflets" with a predominantly circumferential anisotropy.

Understanding remodeling of the fibrous collagen network in response to static and dynamic loads - relevant for (neo)tissue adaptation and homeostasis - has evolved significantly over the years. To provide for a mechanistic understanding, these models include collagen synthesis and degradation profiles, as well as the impact of cellular traction forces resulting from intracellular actin stress fibers (125). Recently, these models have been calibrated against a number of experimental observations, demonstrating a remarkably accurate description of the collagen remodeling in native heart valves (126). Yet, they also reveal the complexity of the interplay between valve geometry, the evolving structural and mechanical properties of the tissue, and traction forces generated by the cells, thereby demonstrating the grand challenges in predicting neo-tissue formation and homeostasis in scaffold-driven in situ HVTE.

When using a fibrous scaffold as a starter matrix for in situ tissue engineering, computational models can provide the initial guidelines with respect to the geometry, mechanical properties, and - in particular - the fiber alignment that controls the degree of anisotropy of the leaflets (127). It is the combination of these properties that determines the deformation patterns in the leaflets that, together with the contact guidance provided by the fibers, dictates the alignment of the endogenously synthesized collagen network (128), and thereby the mechanical functionality of the valve (129).

The next modeling challenge will be the analysis of evolving neo-tissue formation under various scaffold degradation profiles. Our preclinical studies have shown several stages in the process of tissue formation (55). Next to the deposition of collagen and elastin fibers inside the scaffold, significant tissue formation on top of the scaffold is observed, and with time a layered architecture develops. In regions with (near) complete scaffold degradation the tissue composition is markedly different from those with incomplete scaffold degradation. To analyze this staged tissue formation, advanced analysis tools are needed that not only account for mechanical cues, but also for cell signaling mechanisms driven by these cues to describe the complicated processes of growth and remodeling and to predict tissue self organization in situ. For example, it has been shown that Notch signaling has a profound impact on the layered architecture in heart valves and new models should incorporate this signaling (130). When established, such models may be extended with more (and even genetically affected) signaling pathways to provide insights in the requirements for scaffolds that drive tissue formation and ultimately tissue stability and functionality in a variety of pathological conditions.

\section{CLINICAL PERSPECTIVE}

Today, the question remains whether HVTE will ever make a difference. Yet, significant progress has been made and different concepts are being prepared for translation to the clinic (131). We have no doubt that material-based in situ HVTE will leave its footprint on the ongoing quest for a living heart valve replacement. Albeit scientifically and technically extremely challenging, the in situ approach may be more attractive to apply in clinic than other tissue engineering approaches as it will eliminate cell and tissue culture, can be easily scaled up to therapeutic needs, and may be developed into personalized therapies, while at the same reducing regulatory complexity. As such, the approach can bring living valve replacement therapy to many patients worldwide and will not just cater to the wealthy.

Obviously, tackling the above challenges will determine whether we reach this goal, or whether in situ HVTE will remain an academic exercise. A combination of multidisciplinary research - unveiling the mechanisms, potential and limitations of the postnatal human body to adequately respond to the implanted biomaterial scaffold and technological advancements - relating to scaffold development and the prediction of tissue adaptation under various conditions - is essential to take the next step en route to clinical application. This step should include rigorous and extensive preclinical evaluation in direct comparison with in vitro and in silico studies to scrutinize and optimize the technology. Next, a number of reliable, well-regulated randomized clinical trials should be performed for which standardized procedures and endpoints are defined (132). In parallel, simulation models should be developed that estimate the quality of life of patients as well as costeffectiveness of the new technology compared with existing valvular replacement therapies. These measures will support decision makers in their authorization strategy and will aid patients and doctors in 
their choice of a prosthetic valve (133), thereby contributing to a cautious, realistic, and rewarding clinical translation.

\section{AUTHOR CONTRIBUTIONS}

CB suggested the subject of the review and drafted the outline of the manuscript. $\mathrm{CB}, \mathrm{AS}$, and $\mathrm{FB}$ drafted and edited the contents of the manuscript.

\section{FUNDING}

This work was supported by the BMM iValve and iValve-II projects, co-funded by the Dutch Ministry of Economic Affairs

\section{REFERENCES}

1. Hufnagel CA, Harvey WP, Rabil PJ, Mcdermott TF. Surgical correction of aortic insufficiency. Surgery (1954) 35:673-83.

2. Carpentier A, Lemaigre G, Robert L, Carpentier S, Dubost C. Biological factors affecting long-term results of valvular heterografts. J Thorac Cardiovasc Surg (1969) 58:467-83.

3. Elkins RC, Dawson PE, Goldstein S, Walsh SP, Black KS. Decellularized human valve allografts. Ann Thorac Surg (2001) 71(5):S428-S432. doi: 10.1016/S00034975(01)02503-6

4. Bonhoeffer P, Boudjemline Y, Saliba Z, Hausse AO, Aggoun Y, Bonnet D, et al. Transcatheter implantation of a bovine valve in pulmonary position : a lamb study. Circulation (2000) 102(7):813-6. doi: 10.1161/01.CIR.102.7.813

5. Langer R, Vacanti J. Tissue engineering. Science (1993) 260(5110):920-6. doi: $10.1126 /$ science. 8493529

6. Lupinetti FM, Duncan BW, Scifres AM, Fearneyhough CT, Kilian K, Rosenthal GL, et al. Intermediate-term results in pediatric aortic valve replacement. Ann Thorac Surg (1999) 68(2):521-5. doi: 10.1016/S0003-4975(99)00642-6

7. Shinoka T, Breuer CK, Tanel RE, Zund G, Miura T, Ma PX, Px M, et al. Tissue engineering heart valves: Valve leaflet replacement study in a lamb model. Ann Thorac Surg (1995) 60:S513-S516. doi: 10.1016/0003-4975(95)00733-4

8. Hoerstrup SP, Sodian R, Daebritz S, Wang J, Bacha EA, Martin DP, et al. Functional living trileaflet heart valves grown in vitro. Circulation (2000) 102(19 Suppl 3):III-44--40. doi: 10.1161/01.CIR.102.suppl_3.III-44

9. Mol Aet al. Autologous human tissue-engineered heart valves: prospects for systemic application. Circulation (2006) 114(1_suppl):I-152-8. doi: 10.1161/ CIRCULATIONAHA.105.001123

10. Weber B, Scherman J, Emmert MY, Gruenenfelder J, Verbeek R, Bracher M, et al. Injectable living marrow stromal cell-based autologous tissue engineered heart valves: first experiences with a one-step intervention in primates. Eur Heart J (2011) 32(22):2830-40. doi: 10.1093/eurheartj/ehr059

11. Puperi DS, Kishan A, Punske ZE, Wu Y, Cosgriff-Hernandez E, West JL, et al. Electrospun polyurethane and hydrogel composite scaffolds as biomechanical mimics for aortic valve tissue engineering. ACS Biomater Sci Eng (2016) 2(9):1546-58. doi: 10.1021/acsbiomaterials.6b00309

12. Wu S, Duan B, Qin X, Butcher JT. Living nano-micro fibrous woven fabric/ hydrogel composite scaffolds for heart valve engineering. Acta Biomater (2017) 51:89-100. doi: 10.1016/j.actbio.2017.01.051

13. Schmidt D, Dijkman PE, Driessen-Mol A, Stenger R, Mariani C, Puolakka A, et al. Minimally-invasive implantation of living tissue engineered heart valves: a comprehensive approach from autologous vascular cells to stem cells. J Am Coll Cardiol (2010) 56:510-20.

14. Gottlieb D, Kunal T, Emani S, Aikawa E, Brown DW, Powell AJ, et al. In vivo monitoring of function of autologous engineered pulmonary valve. J Thorac Cardiovasc Surg (2010) 139(3):723-31. doi: 10.1016/j.jtcvs.2009.11.006

15. Flanagan TC, Sachweh JS, Frese J, Schnöring H, Gronloh N, Koch S, et al. In vivo remodeling and structural characterization of fibrin-based tissue- and the Netherlands Heart Foundation. AS received funding from the Netherlands Cardio Vascular Research Initiative: the Netherlands Heart Foundation, Dutch Federation of University Medical Centers, the Netherlands Organization for Health Research and Development and the Royal Netherlands Academy of Arts and Sciences (CVON 1Valve). We gratefully acknowledge the financial support by the Ministry of Education, Culture and Science for the Gravitation Program 024.003.103 "Materials Driven Regeneration".

\section{ACKNOWLEDGMENTS}

We acknowledge Dr. E.L. (Leda) Klouda for her critical review of the manuscript.

engineered heart valves in the adult sheep model. Tissue Eng Part A (2009) 15(10):2965-76. doi: 10.1089/ten.tea.2009.0018

16. Loerakker S, Ristori T, Baaijens FPT. A computational analysis of cell-mediated compaction and collagen remodeling in tissue-engineered heart valves. J Mech Behav Biomed Mater (2016) 58:173-87. doi: 10.1016/j.jmbbm.2015.10.001

17. Zilla P, Brink J, Human P, Bezuidenhout D. Prosthetic heart valves: Catering for the few. Biomaterials (2008) 29(4):385-406. doi: 10.1016/j. biomaterials.2007.09.033

18. Yacoub MH, Takkenberg JJM. Will heart valve tissue engineering change the world? Nat Clin Pract Cardiovasc Med (2005) 2(2):60-1. doi: 10.1038/ ncpcardio0112

19. Iop L, Bonetti A, Naso F, Rizzo S, Cagnin S, Bianco R, et al. Decellularized allogeneic heart valves Demonstrate Self-regeneration potential after a longterm preclinical evaluation. PLoS One (2014) 9(6):e99593. doi: 10.1371/ journal.pone.0099593

20. Theodoridis K, Tudorache I, Calistru A, Cebotari S, Meyer T, Sarikouch S, et al. Successful matrix guided tissue regeneration of decellularized pulmonary heart valve allografts in elderly sheep. Biomaterials (2015) 52:221-8. doi: 10.1016/j.biomaterials.2015.02.023

21. Baraki H, Tudorache I, Braun M, Höffler K, Görler A, Lichtenberg A, et al. Orthotopic replacement of the aortic valve with decellularized allograft in a sheep model. Biomaterials (2009) 30(31):6240-6. doi: 10.1016/j. biomaterials.2009.07.068

22. Leyh RG, Wilhelmi M, Rebe P, Fischer S, Kofidis T, Haverich A, et al. In vivo repopulation of xenogeneic and allogeneic acellular valve matrix conduits in the pulmonary circulation. Ann Thorac Surg (2003) 75(5):1457-63. doi: 10.1016/S0003-4975(02)04845-2

23. della Barbera M, Valente M, Basso C, Thiene G. Morphologic studies of cell endogenous repopulation in decellularized aortic and pulmonary homografts implanted in sheep. Cardiovasc Pathol (2015) 24(2):102-9. doi: 10.1016/j. carpath.2014.10.001

24. Tudorache I, Theodoridis K, Baraki H, Sarikouch S, Bara C, Meyer T, et al. Decellularized aortic allografts versus pulmonary autografts for aortic valve replacement in the growing sheep model: haemodynamic and morphological results at 20 months after implantation. Eur J Cardiothorac Surg (2016) 49(4):1228-38. doi: 10.1093/ejcts/ezv362

25. Hopkins RA, Jones AL, Wolfinbarger L, Moore MA, Bert AA, Lofland GK. Decellularization reduces calcification while improving both durability and 1-year functional results of pulmonary homograft valves in juvenile sheep. $J$ Thorac Cardiovasc Surg (2009) 137(4):907-13. doi: 10.1016/j.jtcvs.2008.12.009

26. Neumann A, Sarikouch S, Breymann T, Cebotari S, Boethig D, Horke A et al. Early systemic cellular immune response in children and young adults receiving decellularized fresh allografts for pulmonary valve replacement. Tissue Eng Part A (2014) 20(5-6):1003-11. doi: 10.1089/ten.tea.2013.0316

27. Cebotari S, Tudorache I, Ciubotaru A, Boethig D, Sarikouch S, Goerler A, et al. Use of fresh decellularized allografts for pulmonary valve replacement may reduce the reoperation rate in children and young adults: 
early report. Circulation (2011) 124(11_suppl_1):S115-23. doi: 10.1161/ CIRCULATIONAHA.110.012161

28. Sarikouch S, Horke A, Tudorache I, Beerbaum P, Westhoff-Bleck M, Boethig D, et al. Decellularized fresh homografts for pulmonary valve replacement: a decade of clinical experience. Eur J Cardiothorac Surg (2016) 50(2):281-90. doi: 10.1093/ejcts/ezw050

29. Hopkins RA, Bert AA, Hilbert SL, Quinn RW, Brasky KM, Drake WB, et al. Bioengineered human and allogeneic pulmonary valve conduits chronically implanted orthotopically in baboons: Hemodynamic performance and immunologic consequences. J Thorac Cardiovasc Surg (2013) 145(4):1098107. doi: $10.1016 /$ j.jtcvs.2012.06.024

30. Quinn RW, Bert AA, Converse GL, Buse EE, Hilbert SL, Drake WB, et al. Performance of allogeneic bioengineered replacement pulmonary valves in rapidly growing young lambs. J Thorac Cardiovasc Surg (2016) 152(4):115665. doi: 10.1016/j.jtcvs.2016.05.051

31. Goecke T, Theodoridis K, Tudorache I, Ciubotaru A, Cebotari S, Ramm R, et al. In vivo performance of freeze-dried decellularized pulmonary heart valve allo- and xenografts orthotopically implanted into juvenile sheep. Acta Biomater (2018) 68:41-52. doi: 10.1016/j.actbio.2017.11.041

32. Rieder E, Kasimir M-T, Silberhumer G, Seebacher G, Wolner E, Simon P, et al. Decellularization protocols of porcine heart valves differ importantly in efficiency of cell removal and susceptibility of the matrix to recellularization with human vascular cells. J Thorac Cardiovasc Surg (2004) 127(2):399-405. doi: $10.1016 /$ j.jtcvs.2003.06.017

33. Schneider M, Stamm C, Brockbank KGM, Stock UA, Seifert M. The choice of cryopreservation method affects immune compatibility of human cardiovascular matrices. Sci Rep (2017) 7(1):1-14. doi: 10.1038/s41598-01717288-z

34. Vedepo MC, Detamore MS, Hopkins RA, Converse GL. Recellularization of decellularized heart valves: Progress toward the tissue-engineered heart valve. J Tissue Eng (2017) 8:2041731417726327. doi: 10.1177/2041731417726327

35. Juthier F, Vincentelli A, Gaudric J, Corseaux D, Fouquet O, Calet C, et al. Decellularized heart valve as a scaffold for in vivo recellularization: Deleterious effects of granulocyte colony-stimulating factor. $J$ Thorac Cardiovasc Surg (2006) 131(4):843-52. doi: 10.1016/j.jtcvs.2005.11.037

36. Ota T, Sawa Y, Iwai S, Kitajima T, Ueda Y, Coppin C, et al. Fibronectinhepatocyte growth factor enhances reendothelialization in tissue-engineered heart valve. Ann Thorac Surg (2005) 80(5):1794-801. doi: 10.1016/j. athoracsur.2005.05.002

37. Williams JK, Miller ES, Lane MR, Atala A, Yoo JJ, Jordan JE. Characterization of CD133 Antibody-Directed Recellularized Heart Valves. J Cardiovasc Transl Res (2015) 8(7):411-20. doi: 10.1007/s12265-015-9651-3

38. Stamm C, Khosravi A, Grabow N, Schmohl K, Treckmann N, Drechsel A, et al. Biomatrix/polymer composite material for heart valve tissue engineering. Ann Thorac Surg (2004) 78(6):2084-93. doi: 10.1016/j.athoracsur.2004.03.106

39. Wu S, Liu Y-L, Cui B, Qu X-H, Chen G-Q. Study on decellularized porcine aortic valve/poly (3-hydroxybutyrate-co-3-hydroxyhexanoate) hybrid heart valve in sheep model. Artif Organs (2007) 31(9):689-97. doi: 10.1111/j.15251594.2007.00442.x

40. Hofmann M, Schmiady MO, Burkhardt BE, Dave HH, Hübler M, Kretschmar $\mathrm{O}$, et al. Congenital aortic valve repair using CorMatrix " : A histologic evaluation. Xenotransplantation (2017) 24(6):1-9. doi: 10.1111/xen.12341

41. Woo JS, Fishbein MC, Reemtsen B. Histologic examination of decellularized porcine intestinal submucosa extracellular matrix (CorMatrix) in pediatric congenital heart surgery. Cardiovasc Pathol (2016) 25(1):12-17. doi: 10.1016/j. carpath.2015.08.007

42. Zaidi AH, Nathan M, Emani S, Baird C, del Nido PJ, Gauvreau K, et al. Preliminary experience with porcine intestinal submucosa (CorMatrix) for valve reconstruction in congenital heart disease: Histologic evaluation of explanted valves. J Thorac Cardiovasc Surg (2014) 148(5):2216-25. doi: 10.1016/j.jtcvs.2014.02.081

43. Ropcke DM, Ilkjaer C, Tjornild MJ, Skov SN, Ringgaard S, Hjortdal VE, et al. Small intestinal submucosa tricuspid valve tube graft shows growth potential, remodelling and physiological valve function in a porcine model. Interact Cardiovasc Thorac Surg (2017) 24(6):918-24. doi: 10.1093/icvts/ ivx017

44. Ropcke DM, Rasmussen J, Ilkjær C, Skov SN, Tjørnild MJ, Baandrup UT, et al. Mid-term function and remodeling potential of tissue engineered tricuspid valve: Histology and biomechanics. J Biomech (2018) 71:52-8. doi: 10.1016/j. jbiomech.2018.01.019

45. Driessen-Mol A, Emmert MY, Dijkman PE, Frese L, Sanders B, Weber B, et al. Transcatheter implantation of homologous "off-the-shelf" tissue-engineered heart valves with self-repair capacity: long-term functionality and rapid in vivo remodeling in sheep. J Am Coll Cardiol (2014) 63:1320-9.

46. Weber B, Dijkman PE, Scherman J, Sanders B, Emmert MY, Grünenfelder $\mathrm{J}$, et al. Off-the-shelf human decellularized tissue-engineered heart valves in a non-human primate model. Biomaterials (2013) 34(30):7269-80. doi: 10.1016/j.biomaterials.2013.04.059

47. Spriestersbach H, Prudlo A, Bartosch M, Sanders B, Radtke T, Baaijens FPT, et al. First percutaneous implantation of a completely tissue-engineered selfexpanding pulmonary heart valve prosthesis using a newly developed delivery system: a feasibility study in sheep. Cardiovasc Interv Ther (2017) 32(1):36-7. doi: 10.1007/s12928-016-0396-y

48. Syedain Z, Reimer J, Schmidt J, Lahti M, Berry J, Bianco R, et al. 6-Month aortic valve implantation of an off-the-shelf tissue-engineered valve in sheep. Biomaterials (2015) 73:175-84. doi: 10.1016/j.biomaterials.2015.09.016

49. Reimer J, Syedain Z, Haynie B, Lahti M, Berry J, Tranquillo R. Implantation of a Tissue-engineered tubular heart valve in growing lambs. Ann Biomed Eng (2017) 45(2):439-51. doi: 10.1007/s10439-016-1605-7

50. Weber B, Scherman J, Emmert MY, Gruenenfelder J, Verbeek R, Bracher M, et al. Injectable living marrow stromal cell-based autologous tissue engineered heart valves: first experiences with a one-step intervention in primates. Eur Heart J (2011) 32(22):2830-40. doi: 10.1093/eurheartj/ehr059

51. Emmert MY, Weber B, Behr L, Sammut S, Frauenfelder T, Wolint P, et al. Transcatheter aortic valve implantation using anatomically oriented, marrow stromal cell-based, stented, tissue-engineered heart valves: technical considerations and implications for translational cell-based heart valve concepts. Eur J Cardiothorac Surg (2014) 45(1):61-8. doi: 10.1093/ejcts/ezt243

52. Capulli AK, Emmert MY, Pasqualini FS, Kehl D, Caliskan E, Lind JU, et al. JetValve: Rapid manufacturing of biohybrid scaffolds for biomimetic heart valve replacement. Biomaterials (2017) 133:229-41. doi: 10.1016/j. biomaterials.2017.04.033

53. Bennink G, Torii S, Brugmans M, Cox M, Svanidze O, Ladich E, et al. A novel restorative pulmonary valved conduit in a chronic sheep model: Mid-term hemodynamic function and histologic assessment. J Thorac Cardiovasc Surg (2017). doi.

54. Serruys P, Miyazaki Y, Katsikis A, Abdelghani M, Leon M, Virmani R, et al. Restorative valve therapy by endogenous tissue restoration: tomorrow's world? Reflection on the EuroPCR 2017 session on endogenous tissue restoration. EuroIntervention (2017) 13(AA):AA68-AA77. doi: 10.4244/ EIJ-D-17-00509

55. Kluin J, Talacua H, Smits AIPM, Emmert MY, Brugmans MCP, Fioretta ES, et al. In situ heart valve tissue engineering using a bioresorbable elastomeric implant - From material design to 12 months follow-up in sheep. Biomaterials (2017) 125:101-17. doi: 10.1016/j.biomaterials.2017.02.007

56. Dijkman PE, Driessen-Mol A, Frese L, Hoerstrup SP, Baaijens FPT. Decellularized homologous tissue-engineered heart valves as off-the-shelf alternatives to xeno- and homografts. Biomaterials (2012) 33(18):4545-54. doi: 10.1016/j.biomaterials.2012.03.015

57. Reimer JM, Syedain ZH, Haynie BHT, Tranquillo RT. Pediatric tubular pulmonary heart valve from decellularized engineered tissue tubes. Biomaterials (2015) 62:88-94. doi: 10.1016/j.biomaterials.2015.05.009

58. Jordan JE, Williams JK, Lee S-J, Raghavan D, Atala A, Yoo JJ, et al. Bioengineered self-seeding heart valves. J Thorac Cardiovasc Surg (2012) 143(1):201-8. doi: 10.1016/j.jtcvs.2011.10.005

59. Bouten CVC, Driessen-Mol A, Baaijens FPT. In situ heart valve tissue engineering: simple devices, smart materials, complex knowledge. Expert Rev Med Devices (2012) 9(5):453-5. doi: 10.1586/erd.12.43

60. Li S, Sengupta D, Chien S. Vascular tissue engineering: from in vitro to in situ. Wiley Interdiscip Rev Syst Biol Med (2014) 6(1):61-76. doi: 10.1002/ wsbm.1246

61. Pashneh-Tala S, Macneil S, Claeyssens F. The Tissue-Engineered Vascular Graft-Past, Present, and Future. Tissue Eng Part B (2016) 22:68-100.

62. Miyazaki Y, Soliman O, Abdelghani M, Katsikis A, Naz C, Lopes S, et al. Acute performance of a novel restorative transcatheter aortic valve: preclinical results. EuroIntervention (2017) 13(12):e1410-7. doi: 10.4244/EIJ-D-17-00554 
63. Wissing TB, Bonito V, Bouten CVC, Smits AIPM. Biomaterial-driven in situ cardiovascular tissue engineering-a multi-disciplinary perspective. NPJ Regen Med (2017) 2(2-171):18. doi. doi: 10.1038/s41536-017-0023-2

64. Roh JD, Sawh-Martinez R, Brennan MP, Jay SM, Devine L, Rao DA, et al. Tissue-engineered vascular grafts transform into mature blood vessels via an inflammation-mediated process of vascular remodeling. Proc Natl Acad Sci U S A (2010) 107(10):4669-74. doi: 10.1073/pnas.0911465107

65. Godwin JW, Pinto AR, Rosenthal NA. Macrophages are required for adult salamander limb regeneration. Proc Natl Acad Sci U S A (2013) 110(23):941520. doi: $10.1073 /$ pnas. 1300290110

66. Petrie TA, Strand NS, Tsung-Yang C, Rabinowitz JS, Moon RT. Macrophages modulate adult zebrafish tail fin regeneration. Development (2014) 141(13):2581-91. doi: 10.1242/dev.098459

67. Simkin J, Gawriluk TR, Gensel JC, Seifert AW. Macrophages are necessary for epimorphic regeneration in African spiny mice. eLife (2017) 6. doi. doi: 10.7554/eLife.24623

68. Hibino N, Yi T, Duncan DR, Rathore A, Dean E, Naito Y, et al. A critical role for macrophages in neovessel formation and the development of stenosis in tissue-engineered vascular grafts. FASEB J (2011) 25(12):4253-63. doi: 10.1096/fi.11-186585

69. Wissing TB, Bonito V, Bouten CVC, Smits AIPM. Biomaterial-driven in situ cardiovascular tissue engineering-a multi-disciplinary perspective. NPJ Regen Med (2017) 2(2-171):18. doi. doi: 10.1038/s41536-017-0023-2

70. Brown BN, Londono R, Tottey S, Zhang L, Kukla KA, Wolf MT, et al. Macrophage phenotype as a predictor of constructive remodeling following the implantation of biologically derived surgical mesh materials. Acta Biomater (2012) 8(3):978-87. doi: 10.1016/j.actbio.2011.11.031

71. Badylak SF, Valentin JE, Ravindra AK, McCabe GP, Stewart-Akers AM. Macrophage phenotype as a determinant of biologic scaffold remodeling. Tissue Eng Part A (2008) 14:1835-42.

72. Stadtler K, Estrellas K, Allen BW, Wolf MT, Fan H, Tam AJ, et al. Developing a pro-regenerative biomaterial scaffold microenvironment requires $\mathrm{T}$ helper 2 cells. Science (2016) 15:366-70.

73. Hibino N, Villalona G, Pietris N, Duncan DR, Schoffner A, Roh JD, et al. Tissue-engineered vascular grafts form neovessels that arise from regeneration of the adjacent blood vessel. The FASEB Journal (2011) 25(8):2731-9. doi: 10.1096/fi.11-182246

74. Pennel T, Bezuidenhout D, Koehne J, Davies NH, Zilla P. Transmural capillary ingrowth is essential for confluent vascular graft healing. Acta Biomater (2018) 65:237-47. doi: 10.1016/j.actbio.2017.10.038

75. Talacua H, Smits AIPM, Muylaert DEP, van Rijswijk JW, Vink A, Verhaar MC, et al. In Situ tissue engineering of functional small-diameter blood vessels by host circulating cells only. Tissue Eng Part A (2015) 21(19-20):2583-94. doi: 10.1089/ten.tea.2015.0066

76. de Visscher G, Plusquin R, Mesure L, Flameng W. Selection of an immunohistochemical panel for cardiovascular research in sheep. Appl Immunohistochem Mol Morphol (2010) 18(4):382-91. doi: 10.1097/ PAI.0b013e3181cd32e7

77. Seok J, Warren HS, Cuenca AG, Mindrinos MN, Baker HV, Xu W, et al. Genomic responses in mouse models poorly mimic human inflammatory diseases. Proc Natl Acad Sci U S A (2013) 110(9):3507-12. doi: 10.1073/ pnas. 1222878110

78. Spiller KL, Wrona EA, Romero-Torres S, Pallotta I, Graney PL, Witherel CE, et al. Differential gene expression in human, murine, and cell line-derived macrophages upon polarization. Exp Cell Res (2016) 347(1):1-13. doi: 10.1016/j.yexcr.2015.10.017

79. Mestas J, Hughes CCW. Of mice and not men: differences between mouse and human immunology. J Immunol (2004) 172(5):2731-8. doi: 10.4049/ jimmunol.172.5.2731

80. Hachim D, Wang N, Lopresti ST, Stahl EC, Umeda YU, Rege RD, et al. Effects of aging upon the host response to implants. J Biomed Mater Res A (2017) 105(5):1281-92. doi: 10.1002/jbm.a.36013

81. Levy O. Innate immunity of the newborn: basic mechanisms and clinical correlates. Nat Rev Immunol (2007) 7(5):379-90. doi: 10.1038/nri2075

82. Socarrás TO, Vasconcelos AC, Campos PP, Pereira NB, Souza JPC, Andrade SP. Foreign body response to subcutaneous implants in diabetic rats. PLoS One (2014) 9(11):e110945. doi: 10.1371/journal.pone.0110945
83. Wang Z, Zheng W, Wu Y, Wang J, Zhang X, Wang K, et al. Differences in the performance of PCL-based vascular grafts as abdominal aorta substitutes in healthy and diabetic rats. Biomater Sci (2016) 4(10):1485-92. doi: 10.1039/ C6BM00178E

84. Kooman JP, Dekker MJ, Usvyat LA, Kotanko P, van der Sande FM, Schalkwijk CG, et al. Inflammation and premature aging in advanced chronic kidney disease. Am J Physiol Renal Physiol (2017) 313(4):F938-F950. doi: 10.1152/ ajprenal.00256.2017

85. Simionescu A, Schulte JB, Fercana G, Simionescu DT. Inflammation in cardiovascular tissue engineering: The challenge to a promise: A Minireview. Int J Inflammation (2011) ID 958247. doi.

86. Wolf F, Vogt F, Schmitz-Rode T, Jockenhoevel S, Mela P. Bioengineered vascular constructs as living models for in vitro cardiovascular research. Drug Discov Today (2016) 21(9):1446-55. doi: 10.1016/j. drudis.2016.04.017

87. Zhu AS, Grande-Allen KJ. Heart valve tissue engineering for valve replacement and disease modeling. Curr Opin Biomed Eng (2018) 5:35-41. doi: 10.1016/j. cobme.2017.12.006

88. Smits AI, Driessen-Mol A, Bouten CV, Baaijens FP. A mesofluidics-based test platform for systematic development of scaffolds for in situ cardiovascular tissue engineering. Tissue Eng Part C Methods (2012) 18(6):475-85. doi: 10.1089/ten.tec.2011.0458

89. Smits AIPM, Ballotta V, Driessen-Mol A, Bouten CVC, Baaijens FPT. Shear flow affects selective monocyte recruitment into MCP-1-loaded scaffolds. J Cell Mol Med (2014) 18(11):2176-88. doi: 10.1111/jcmm.12330

90. Sanders B, Driessen-Mol A, Bouten CVC, Baaijens FPT. The effects of scaffold remnants in decellularized tissue-engineered cardiovascular constructs on the recruitment of blood cells. Tissue Eng Part A (2017) 23(19-20):1142-51. doi: 10.1089/ten.tea.2016.0503

91. Battiston KG, Labow RS, Simmons CA, Santerre JP. Immunomodulatory polymeric scaffold enhances extracellular matrix production in cell co-cultures under dynamic mechanical stimulation. Acta Biomater (2015) 24:74-86. doi: 10.1016/j.actbio.2015.05.038

92. Ballotta V, Driessen-Mol A, Bouten CVC, Baaijens FPT. Strain-dependent modulation of macrophage polarization within scaffolds. Biomaterials (2014) 35(18):4919-28. doi: 10.1016/j.biomaterials.2014.03.002

93. Boersema GSA, Utomo L, Bayon Y, Kops N, van der Harst E, Lange JF, et al. Monocyte subsets in blood correlate with obesity related response of macrophages to biomaterials in vitro. Biomaterials (2016) 109:32-9. doi: 10.1016/j.biomaterials.2016.09.009

94. Simionescu D, Jaeggli M, Liao J, Simionescu A. Translational personalized regenerative medicine; scaffolds and stem cells for patient-tailored aortic heart valve tissue engineering. Cardiology (2012) 121:138.

95. Wang RM, Johnson TD, He J, Rong Z, Wong M, Nigam V, et al. Humanized mouse model for assessing the human immune response to xenogeneic and allogeneic decellularized biomaterials. Biomaterials (2017) 129:98-110. doi: 10.1016/j.biomaterials.2017.03.016

96. Yang H, Wang H, Jaenisch R. Generating genetically modified mice using CRISPR/Cas-mediated genome engineering. Nat Protoc (2014) 9(8):1956-68. doi: 10.1038/nprot.2014.134

97. Zhang W, Wang G, Wang Y, Jin Y, Zhao L, Xiong Q, et al. Generation of complement protein C3 deficient pigs by CRISPR/Cas9-mediated gene targeting. Sci Rep (2017) 7(1):5009. doi. doi: 10.1038/s41598-017-05400-2

98. Langer R, Tirrell DA. Designing materials for biology and medicine. Nature (2004) 428(6982):487-92. doi: 10.1038/nature02388

99. Murphy WL, Mcdevitt TC, Engler AJ. Materials as stem cell regulators. Nat Mater (2014) 13(6):547-57. doi: 10.1038/nmat3937

100. Huebsch N, Mooney DJ. Inspiration and application in the evolution of biomaterials. Nature (2009) 462(7272):426-32. doi: 10.1038/nature08601

101. Dankers PY, Harmsen MC, Brouwer LA, van Luyn MJ, Meijer EW. A modular and supramolecular approach to bioactive scaffolds for tissue engineering. Nat Mater (2005) 4(7):568-74. doi: 10.1038/nmat1418

102. Webber MJ, Appel EA, Meijer EW, Langer R. Supramolecular biomaterials. Nat Mater (2016) 15(1):13-26. doi: 10.1038/nmat4474

103. Muylaert DE, van Almen GC, Talacua H, Fledderus JO, Kluin J, Hendrikse SI, et al. Early in-situ cellularization of a supramolecular vascular graft is modified by synthetic stromal cell-derived factor-1a derived peptides. Biomaterials (2016) 76:187-95. doi: 10.1016/j.biomaterials.2015.10.052 
104. Ballotta V, Smits AI, Driessen-Mol A, Bouten CV, Baaijens FP. Synergistic protein secretion by mesenchymal stromal cells seeded in $3 \mathrm{D}$ scaffolds and circulating leukocytes in physiological flow. Biomaterials (2014) 35(33):910013. doi: 10.1016/j.biomaterials.2014.07.042

105. Garg K, Pullen NA, Oskeritzian CA, Ryan JJ, Bowlin GL. Macrophage functional polarization (M1/M2) in response to varying fiber and pore dimensions of electrospun scaffolds. Biomaterials (2013) 34(18):4439-51. doi: 10.1016/j.biomaterials.2013.02.065

106. Bouten CV, Dankers PY, Driessen-Mol A, Pedron S, Brizard AM, Baaijens FP. Substrates for cardiovascular tissue engineering. Adv Drug Deliv Rev (2011) 63(4-5):221-41. doi: 10.1016/j.addr.2011.01.007

107. Nachlas ALY, Li S, Davis ME. Developing a review of Current Approaches. Adv Healthc Mater (2017) 6(24):1700918. doi: 10.1002/adhm.201700918

108. Simonet M, Driessen - Mol A, Baaijens FPT, Bouten CVC. Heart valve tissue regeneration. In: Bosworth L, Downes S, editors. Electrospinning for tissue regeneration. Cambridge: Woodhead Publishing Limited (2011). p. 202-24.

109. del Gaudio C, Grigioni M, Bianco A, de Angelis G. Electrospun bioresorbable heart valve scaffold for tissue engineering. Int J Artif Organs (2008) 31(1):6875. doi: 10.1177/039139880803100110

110. Hockaday LA, Kang KH, Colangelo NW, Cheung PY, Duan B, Malone E, et al. Rapid 3D printing of anatomically accurate and mechanically heterogeneous aortic valve hydrogel scaffolds. Biofabrication (2012) 4(3):035005. doi: 10.1088/1758-5082/4/3/035005

111. Ristovski N, Bock N, Liao S, Powell SK, Ren J, Kirby GT, Gilles TS, et al. Improved fabrication of melt electrospun tissue engineering scaffolds using direct writing and advanced electric field control. Biointerphases (2015) 10(1):011006. doi. doi: 10.1116/1.4914380

112. D'Amore A, Luketich SK, Raffa GM, Olia S, Menallo G, Mazzola A, et al. Heart valve scaffold fabrication: Bioinspired control of macro-scale morphology, mechanics and micro-structure. Biomaterials (2018) 150:25-37. doi: 10.1016/j. biomaterials.2017.10.011

113. Balguid A, Mol A, van Marion MH, Bank RA, Bouten CV, Baaijens FP. Tailoring fiber diameter in electrospun poly(epsilon-caprolactone) scaffolds for optimal cellular infiltration in cardiovascular tissue engineering. Tissue Eng Part A (2009) 15(2):437-44. doi: 10.1089/ten.tea.2007.0294

114. Gross L, Sibbing D, Eickhoff M, Baquet M, Orban M, Krieg A, et al. Impact of the bioresorbable vascular scaffold surface area on on-treatment platelet reactivity. Platelets (2016) 27(5):446-51. doi: 10.3109/09537104.2016.1143918

115. Riool M, de Breij A, Drijfhout JW, Nibbering PH, Zaat SAJ. Antimicrobial peptides in biomedical device manufacturing. Frontiers Chem (2017) 5:63. doi. doi: $10.3389 /$ fchem. 2017.00063

116. Unadkat HV, Hulsman M, Cornelissen K, Papenburg BJ, Truckenmüller RK, Carpenter AE, et al. An algorithm-based topographical biomaterials library to instruct cell fate. Proc Natl Acad Sci U S A (2011) 108(40):16565-70. doi: 10.1073/pnas. 1109861108

117. Vasilevich AS, Carlier A, de Boer J, Singh S. How not to drown in data: a guide for biomaterial engineers. Trends Biotechnol (2017) 35(8):743-55. doi: 10.1016/j.tibtech.2017.05.007

118. Miller KS, Khosravi R, Breuer CK, Humphrey JD. A hypothesis-driven parametric study of effects of polymeric scaffold properties on tissue engineered neovessel formation. Acta Biomater (2015) 11:283-94. doi: 10.1016/j.actbio.2014.09.046

119. Sacks MS, Yoganathan AP. Heart Valve Function: A Biomechanical Perspective. Philosophical Transactions: R Soc Lond B Biol Sci (2007) 362(1484):1369-91. doi: $10.1098 /$ rstb.2007.2122

120. Weinberg EJ, Shahmirzadi D, Mofrad MR. On the multiscale modeling of heart valve biomechanics in health and disease. Biomech Model Mechanobiol (2010) 9(4):373-87. doi: 10.1007/s10237-009-0181-2
121. Driessen NJB, Boerboom RA, Huyghe JMR, Bouten CVC, Baaijens FPT. Computational analyses of mechanically induced collagen fibre remodeling in the aortic heart valve. J Biomech Eng (2003) 125(4):549-57. doi: $10.1115 / 1.1590361$

122. Loerakker S, Argento G, Oomens CW, Baaijens FP. Effects of valve geometry and tissue anisotropy on the radial stretch and coaptation area of tissueengineered heart valves. J Biomech (2013) 46(11):1792-800. doi: 10.1016/j. jbiomech.2013.05.015

123. de Hart J, Peters GW, Schreurs PJ, Baaijens FP. A three-dimensional computational analysis of fluid-structure interaction in the aortic valve. $J$ Biomech (2003) 36(1):103-12. doi: 10.1016/S0021-9290(02)00244-0

124. de Hart J, Peters GW, Schreurs PJ, Baaijens FP. Collagen fibers reduce stresses and stabilize motion of aortic valve leaflets during systole. J Biomech (2004) 37(3):303-11. doi: 10.1016/S0021-9290(03)00293-8

125. Loerakker S, Obbink-Huizer C, Baaijens FP. A physically motivated constitutive model for cell-mediated compaction and collagen remodeling in soft tissues. Biomech Model Mechanobiol (2014) 13(5):985-1001. doi: 10.1007/ s10237-013-0549-1

126. Oomen PJA, Loerakker S, van Geemen D, Neggers J, Goumans MTH, van den Bogaerdt AJ, et al. Age-dependent changes of stress and strain in the human heart valve and their relation with collagen remodeling. Acta Biomater (2016) 29:161-9. doi: 10.1016/j.actbio.2015.10.044

127. Argento G, Simonet M, Oomens CW, Baaijens FP. Multi-scale mechanical characterization of scaffolds for heart valve tissue engineering. J Biomech (2012) 45(16):2893-8. doi: 10.1016/j.jbiomech.2012.07.037

128. de Jonge N, Kanters FM, Baaijens FP, Bouten CV. Strain-induced collagen organization at the micro-level in fibrin-based engineered tissue constructs. Ann Biomed Eng (2013) 41(4):763-74. doi: 10.1007/s10439-012-0704-3

129. Argento G, de Jonge N, Söntjens SH, Oomens CW, Bouten CV, Baaijens FP. Modeling the impact of scaffold architecture and mechanical loading on collagen turnover in engineered cardiovascular tissues. Biomech Model Mechanobiol (2015) 14(3):603-13. doi: 10.1007/s10237-014-0625-1

130. Luna-Zurita L, Prados B, Grego-Bessa J, Luxán G, del Monte G, Benguría $A$, et al. Integration of a Notch-dependent mesenchymal gene program and Bmp2-driven cell invasiveness regulates murine cardiac valve formation. J Clin Invest (2010) 120(10):3493-507. doi: 10.1172/JCI42666

131. Chester AH. Tissue Engineering-Bridging the Gap. J Cardiovasc Transl Res (2017) 10(2):91-2. doi: 10.1007/s12265-017-9749-x

132. Cossu G, Birchall M, Brown T, de Coppi P, Culme-Seymour E, Gibbon S, et al. Lancet Commission: Stem cells and regenerative medicine. Lancet (2018) 391(10123):883-910. doi. doi: 10.1016/S0140-6736(17)31366-1

133. Huygens SA, Rutten-van Mölken MP, Bekkers JA, Bogers AJ, Bouten CV, Chamuleau SA, et al. Conceptual model for early health technology assessment of current and novel heart valve interventions. Open Heart (2016) 3(2):e000500. doi: 10.1136/openhrt-2016-000500

Conflict of Interest Statement: $\mathrm{CB}$ and $\mathrm{FB}$ are non-voting shareholders of XELTIS AG based on intellectual property licensed to XELTIS. The authors declare that the research and the work related to the preparation of this manuscript was performed in the absence of any commercial or financial relationships.

Copyright (c) 2018 Bouten, Smits and Baaijens. This is an open-access article distributed under the terms of the Creative Commons Attribution License (CC BY). The use, distribution or reproduction in other forums is permitted, provided the original author(s) and the copyright owner are credited and that the original publication in this journal is cited, in accordance with accepted academic practice. No use, distribution or reproduction is permitted which does not comply with these terms. 